JOANNA NAPIERAŁA - POZNAŃ

\title{
„PRACA ZA POKOLENIA DLA POKOLEŃ”. 90-LECIE ARCHIWUM ARCHIDIECEZJALNEGO W POZNANIU
}

W przestrzeni kultury archiwa kościelne są «znakiem cywilizacji oraz naszą rezerwą i naszym zasobem dla kościelnej psychologii i duszpasterskiej misji wobec świata» ${ }^{1}$.

W tych słowach abp Stanisław Gądecki metropolita poznański, zwrócił się w przedmowie do polskich czytelników Listu Apostolskiego Jana Pawła II w formie motu proprio «La cura vigilantissima» tj. ustawy regulującej funkcjonowanie archiwów Stolicy Apostolskiej, przygotowanej przez Ojca Świętego Jana Pawła II na krótko przed śmiercią w 2005 roku. Przytoczony cytat w całej istocie oddaje cele, jakimi stara się poświęcać i kierować przez cały okres swojego istnienia Archiwum Archidiecezjalne w Poznaniu. Jego misją było i jest przechowywanie pamięci o historii wiary i samej instytucji Kościoła w Polsce, stając się przez to przedłużeniem jej działalności duszpasterskiej. W 2015 roku Archiwum przeżywało okrągłą rocznicę 90 lat swojego istnienia. To jedna z najstarszych placówek zajmujących się gromadzeniem pamiątek historycznych, stanowiąca repozytorium pamięci Kościoła w Polsce.

Erekcja Archiwum Archidiecezjalnego w Poznaniu miała miejsce 13 października 1925 r. (datę tą uznaje się za właściwy początek działalności tej placówki), jednakże uroczyste otwarcie miało miejsce dopiero 27 maja 1926 roku. Poświęcenia dokonał ówczesny arcybiskup poznański ks. kard. Edmund Dalbor. Była to pierwsza taka placówka w odrodzonej Rzeczypospolitej.

Pomysł, by stworzyć profesjonalnie przygotowane miejsce do przechowywania historycznej spuścizny wielu pokoleń Kościoła Poznańskiego pojawił się już w XIX wieku, na długo przez realizacją tego projektu. Działania w tym kierunku, jako pierwszy podjął abp Florian Stablewski². Jego intencją było zgromadzenie w jednym miejscu zabytków archiwalnych z obydwu archidiecezji - poznańskiej

${ }^{1}$ Cyt. za: S. Gądecki, Przedmowa, w: List Apostolski Jana Pawła II w formie motu proprio «La cura vigilantissima», tłum., R. Rybacki, Poznań 2014, s. 6.

${ }^{2}$ F. Lenort, $Z$ dziejów organizacji $i$ zasobu Archiwum Archidiecezjalnego w Poznaniu, „Archiwa, Biblioteki i Muzea Kościelne” (dalej: ABMK), 15 (1967) s. 66; L. Wilczyński, Archiwum 
i gnieźnieńskiej. Arcybiskup powołał w tym celu Muzeum Archidiecezjalne, w którym wyróżniono osobne działy dla zbiorów archiwalnych i bibliotecznych. Kolejnym krokiem było ustanowienie w 1915 r. przez abpa E. Dalbora stanowiska archiwariusza diecezjalnego. Powołano na to miejsce ks. Kamila Kantaka, którego głównym zadaniem było uporządkowanie akt konsystorskich. Rzeczywistym zorganizowaniem archiwum, jako osobnej instytucji, zajął się dopiero w 1919 r. ks. Edmund Majkowski, kierownik Muzeum Archidiecezjalnego opiekujący się również zasobem biblioteki seminaryjnej. Ks. Majkowski dążył do tego by stworzyć archiwum na miarę tych funkcjonujących wówczas na zachodzie Europy. Planował zgromadzić i opracowywać, prócz akt konsystorskich, także akta Ordynariatu Arcybiskupiego, Kapituly Metropolitalnej, księgozbiór diecezjalny oraz dokumenty i akta parafialne ${ }^{3}$. Właściwą formę placówka ta przybrała dopiero w latach 20 . XX wieku. Nadał ją archiwum dekret erekcyjny ogłoszony 13 października 1925 roku. Dokument ten zawierał siedmiopunktowy statut dla Archiwum Archidiecezjalnego, na mocy, którego stało się ono osobną instytucja diecezjalną, rządzącą się własnymi prawami i posiadającą osobowość prawno-kościelnąa . Wiążącą podstawą prawną dla stworzenia statutu i reorganizacji archiwum, były odpowiednie dyrektywy Kodeksu Prawa Kanonicznego z 1917 r. oraz przeredagowany przez kard. Gasparriego okólnik Sekretariatu Stanu z 1923 roku$^{5}$. Na mocy tak stworzonego dokumentu Archiwum miało bezpośrednio podlegać arcybiskupowi oraz mianowanym przez niego kuratorom i dyrektorom. W dekretach nominacyjnych arcybiskup zobowiązał ich do opracowania regulaminów określających warunki pracy oraz zasady korzystania z zebranego zasobu. Ponadto każdy z wybranych dyrektorów, z racji swego urzędu, miał być konserwatorem diecezjalnym wszystkich archiwów parafialnych i rzeczoznawcą w sprawach archiwalnych ${ }^{6}$.

Statut określał również zadania archiwum, jako placówki poświęconej nauce. Od początku należały do nich gromadzenie, konserwacja oraz udostępnianie zabytków rękopiśmiennych i drukowanych, odnoszących się do dziejów arcybiskupstwa gnieźnieńskiego i poznańskiego 7 . Ostatni punkt dotyczący gromadzenia zbiorów z obu archidiecezji niestety pozostał martwy. Był to projekt trudny do

Archidiecezjalne w Poznaniu w latach 1925-1939, „Archiwariusz. Biuletyn Archiwum Archidiecezjalnego w Poznaniu"(dalej: Archiwariusz), 1 (2005) s. 13.

${ }_{3}^{3}$ Archiwum Państwowe w Poznaniu (dalej: APP), Józef Paczkowski - spuścizna, sygn. 999/30, Otwarcie Archiwum Archidiecezjalnego w Poznaniu i sprawa nawiązania kontraktów w tym, że Archiwum w sprawie scalania akt. Teczka zawiera luźny zbiór korespondencji do Naczelnika Wydziału Archiwów przy Ministerstwie W. R. i O.P. pana Józefa Paczkowskiego.

${ }^{4}$ Por. Archiwum Archidiecezjalne w Poznaniu (dalej: AAP), Konsystorz i Kuria Arcybiskupia, sygn. KA 4387, Archiwum Archidiecezjalne I (1926-1935), k. 1-1v; Archiwum Archidiecezjalne w Poznaniu. Statut dla Archiwum Archidiecezjalnego w Poznaniu, „Miesięcznik Kościelny dla Archidiecezji Gnieźnieńskiej i Poznańskiej” (dalej: MKGiP), 40 (1925) nr 12, s. 96-97.

${ }^{5}$ Lenort, $Z$ dziejów organizacji i zasobu Archiwum, s. 72.

${ }^{6}$ AAP, KA 4387, k. 1-1v.

${ }^{7}$ Por. APP, sygn. 999/30, k. 1; § 1 Statutu dla Archiwum Archidiecezjalnego w Poznaniu, w: MKGiP, 40 (1925) nr 12, s. 96-97. 
zrealizowania głównie ze względu na administracyjny podział obu archidiecezji, jakiego w 1926 roku dokonał abp August Hlond. W związku z tym zdecydowano pozostawić archidiecezji gnieźnieńskiej archiwum kapitulne, akta konsystorskie, biskupie oraz dokumenty jednostek terytorialnych diecezji tj. parafii ${ }^{8}$. Kwestę gromadzenia dokumentacji $\mathrm{w}$ archiwum regulował wydany wraz ze statutem dekret wykonawczy abpa E. Dalbora. Zakładał on obowiązek przekazywania do archiwum „wszystkich zabytków archiwalnych rozproszonych po poszczególnych kościołach i archiwach parafialnych" " W późniejszych latach abp A. Hlond uzupełnił dekret o zakaz zwracania parafiom przekazanych i zdeponowanych $\mathrm{w}$ archiwum zabytków ${ }^{10}$.

Na siedzibę nowo powstałej instytucji archidiecezjalnej obrano gmach dawnej Akademii Lubrańskiego przy ulicy Lubrańskiego 1. Po przeprowadzonej w latach 1924/1925 przebudowie i adaptacji budynku, przeniesiono do niego Archiwum, które funkcjonowało w tym miejscu przeszło 80 lat do 2007 r., kiedy to przeprowadzono je do budynku przy ul. Ignacego Posadzego 2.

Oficjalne otwarcie Archiwum Archidiecezjalnego nastąpiło 27 maja 1926 r. Miało ono wyjątkowo odświętną oprawę. Na uroczystość zaproszeni zostali przedstawiciele najwyższych władz duchownych z biskupem Stanisławem Łukomskim - wikariuszem kapitulnym poznańskim na czele. Z grona władz państwowych i miejskich stawili się prezydent miasta Poznania Cyryl Ratajski, przedstawiciel Archiwum Państwowego w osobie prof. Józefa Paczkowskiego, Naczelnego Dyrektora Archiwów Państwowych reprezentującego również Ministerstwo Wyznań Religijnych i Oświecenia Publicznego. Nie zabrakło także przedstawicieli Uniwersytetu Poznańskiego oraz delegatów innych ważnych placówek naukowo-kulturalnych miasta Poznania. W sumie w uroczystościach otwarcia wzięło udział niemal 100 osób $^{11}$.

Wyjątkową pamiątką z tego wydarzenia jest okolicznościowy medal, wykonany przez Mennicę Państwową według projektu prof. Jana Wysockiego, na którym prócz wizerunku gmachu Akademii i mitycznej Klio, naniesiono inskrypcję: Academia Lubranscana, nobiliter restaurata, scientiis restitua pristinis 1926 (Fot. 1) ${ }^{12}$.

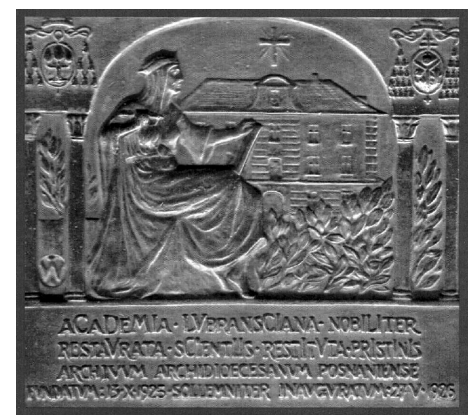

Fot. 1. Medal okolicznościowy z 1926 r., ze zbiorów AAP.

\footnotetext{
${ }^{8}$ Lenort, Z dziejów organizacji i zasobu Archiwum, s. 73.

${ }^{9}$ Tamże, s. 76.

${ }^{10}$ Tamże.

${ }^{11}$ Wilczyński, Archiwum Archidiecezjalne w Poznaniu, s. 20.

${ }^{12}$ Tamże, s. 21.
} 
Pierwszym, który objął urząd dyrektora archiwum był wspomniany ks. Edmund Majkowski. Pozostał on na tym stanowisku do 1933 r. $^{13}$ Swoje nowe zadanie potraktował bardzo poważnie. Jego działania koncentrowały się, co oczywiste $u$ początku funkcjonowania placówki, na gromadzeniu archiwaliów. Na polecenie abpa E. Dalbora, zorganizował również gabinet numizmatyczny, w którym prezentowano ponad 500 monet $^{14}$. Po zakończonej kadencji ks. E. Majkowskiego w 1933 r., stanowisko dyrektora objął ks. Józef Nowacki. Pełnił tę funkcję do śmierci w 1964 r. ${ }^{15}$ Był to okres niebywale intensywnej pracy, która zaowocowała wypracowaniem wyraźnych struktur i wewnętrznej organizacji. Ks. J. Nowacki podjął się najtrudniejszego zadania tj. uporządkowania zgromadzonego zasobu, zinwentaryzowania i poddania go konserwacji. Efektem jego zaangażowania i skrupulatności w inwentaryzowaniu akt był katalog obejmujący księgi konsystorskie, biskupie i kapitulne oraz możliwość udostępniania jego zawartości historykom. W tym celu zorganizował w archiwum osobną pracownię naukową. Okres przewodzenia Archiwum Archidiecezjalnemu przez ks. J. Nowackiego przypadł również na lata okupacji niemieckiej, które okazały się najtrudniejszym czasem w dziejach tej instytucji. W październiku 1939 r. cały magazyn archiwalny został opieczętowany i przygotowany do likwidacji. Ostatecznie zbiory uległy częściowemu zniszczeniu lub rozproszeniu ${ }^{16}$. Tylko dzięki temu, że w czasie wojny ks. Nowacki pracował w Archiwum Państwowym w Poznaniu, możliwe było prze-

${ }^{13}$ Ks. Edmund Majkowski (1892-1951), ur. w Grodzisku Wlkp., założyciel Zbiorów Archiwum i Biblioteki Archidiecezji Poznańskiej. Święcenia kapłańskie przyjął w 1916 r. Studiował w Belgii, Holandii i Francji. Doktorat z filozofii ukończył krótko po wojnie na Katolickim Uniwersytecie Lubelskim. Był czynnym członkiem wielu towarzystw naukowych, chociażby Komisji PAU w dziedzinie mediografii, archiwistyki i bibliotekoznawstwa oraz Instytutu Słowiańskiego w Pradze. Założył Towarzystwo Bibliofilów Poznańskich, pełnił również funkcję korespondenta Akademii Archeologii Belgijskiej. Pod koniec życia, swoje bogate zbiory przekazał instytucja kościelnym a zwłaszcza Katolickiemu Uniwersytetowi Lubelskiemu. Ks. J. Stanisławski, Sylwetki Dyrektorów Archiwum Archidiecezjalnego w Poznaniu - wspomnienie, referat wygłoszony 04.11.2015 r. w trakcie sesji naukowej z okazji jubileuszu 90 lat Archiwum Archidiecezjalnego w Poznaniu (referat nie został opublikowany); Zob. Nekrolog. Śp. Ks. Dr Edmund Majkowski, „Miesięcznik Kościelny Archidiecezji Poznańskiej” (dalej: MKP), 6 (1951) nr 9/10, s. 250-251.

${ }^{14}$ AAP, KA 4387, k. 35.

${ }^{15}$ Ks. prof. kan. Józef Nowacki (1893-1964), ur. we wsi Mrocza. Od 1905 r. uczęszczał do progimnazjum biskupiego w Pelplinie. W 1913 r., zdał maturę w gimnazjum w Chełmnie a następnie wstąpił do Seminarium Duchownego w Poznaniu, gdzie odbył studia filozoficzne i teologiczne, po czym spędził rok na studiach teologii praktycznej w seminarium gnieźnieńskim. Święcenia kapłańskie przyjął 18 lutego 1917 r. W latach 1917-1919 studiował historię Kościoła w Münster. W 1926 r. uzyskał stopień doktora na Wydziale Teologicznym Uniwersytetu Jana Kazimierza we Lwowie. Rok później kard. Hlond mianował go profesorem nadzwyczajnym historii Kościoła i patrologii w Arcybiskupim Seminarium Duchownym w Poznaniu, a już w 1929 r., profesorem zwyczajnym Arcybiskupiego Seminarium Duchownego w Gnieźnie. Swoją habilitacje obronił na Wydziale Teologicznym UJK we Lwowie w 1938 r. Za zasługi dla archidiecezji został mianowany w 1946 r. przez abpa W. Dymka kanonikiem honorowym, a w 1951 r., kanonikiem gremialnym Kapituły Metropolitalnej. Zob. Ks. K. Karłowski, Nekrolog. Śp. Ks. Józef Nowacki, MKP, 16 (1965) nr 5, s. 116-117.

${ }^{16}$ Zob. J. Nowacki, Losy wojenne Archiwum Archidiecezjalnego w Polsce, „Sprawozdania Poznańskiego Towarzystwa Przyjaciół Nauk", 13 (1945/1946), s. 44-46. 
śledzenie losów skradzionych przez okupanta zbiorów. Zapisy, jakie wówczas sporządził pozwoliły na odzyskanie po wojnie sporej części zasobu Archiwum Archidiecezjalnego, jak również zabytków archiwalnych archidiecezji gnieźnieńskiej i wrocławskiej.

Praca ks. Nowackiego w archiwum nie ograniczała się jedynie do funkcji dyrektora. Korzystając z bezpośredniego dostępu do źródeł, wydał on ponad 84 publikacji, w tym swoje czołowe dzieło Dzieje Archidiecezji Poznańskiej, złożone z dwóch tomów: Kościót Katedralny w Poznaniu. Studium Historyczne oraz bardzo cenny dla każdego badacza historii Kościoła w Polsce, tom drugi Archidiecezja Poznańska w granicach historycznych $i$ jej ustrój ${ }^{17}$. Jego wiedza na temat dokumentów kościelnych oraz biegła znajomości łaciny pozwoliła mu również na wydanie kilku istotnych edycji źródłowych. Do najbardziej znanych należy Liber Beneficiorum dioecesis Posnaniensis anni $1510^{18}$. Swoją naukową aktywność wykazywał również, jako członek Poznańsko-Pomorskiego Związku Bibliotekarzy czy Poznańskiego Towarzystwa Przyjaciół Nauk. Po śmierci, ks. J. Nowackiego, na stanowisku dyrektora zastąpił go ks. Stefan Hain, kustosz Archiwum i Muzeum Archidiecezjalnego. Funkcję dyrektora sprawował w latach 1964-1971. W tym czasie ks. S. Hain ${ }^{19}$ kontynuował starania swojego poprzednika o rewindykację rozproszonych zbiorów. Jeszcze jako kustoszowi, udało mu się odzyskać dwa wagony paramentów z różnych kościołów, przeznaczonych na przemiał w zbiornicy surowców wtórnych w Łodzi. Sukcesem zakończyła się także próba odzyskania wysokiej klasy zabytków, jak chociażby 800 dzwonów kościelnych. Również za jego kadencji rozdzielono Muzeum i Archiwum Archidiecezjalne, tworząc z nich dwie odrębne instytucje. Za swoje zasługi dla archidiecezji i archiwum abp Antoni Baraniak w 1962 r. wyjednał mu godność tajnego szambelana ${ }^{20}$.

Na lata 70. XX wieku, przypadła działalność kolejnego dyrektora ks. Mariana Banaszaka ${ }^{21}$. Objął on stanowisko w 1971 roku i zgodnie z wolą abpa A. Bara-

${ }^{17}$ J. Nowacki, Dzieje Archidiecezji Poznańskiej, t. I: Kościót Katedralny w Poznaniu. Studium Historyczne, Poznań 1959; tenże, Dzieje Archidiecezji Poznańskiej, t. II: Archidiecezja Poznańska w granicach historycznych i jej ustrój, Poznań 1964. Ks. Nowacki zamierzał opracować trzecią część Dziejów Archidiecezji, która miała dotyczyć Kapituły Katedralnej. Pracę nad tomem przerwała nagła śmierć autora.

${ }^{18}$ Tenże, Liber Beneficiorum dioecesis Posnaniensis anni 1510, Poznań 1950.

${ }^{19}$ Ks. dr Stefan Hain (1903-1979), ur. w Łagiewnikach k. Poznania. W 1922 r. podjął studia lekarskie, które zmuszony był jednak przerwać ze względu na brak funduszy. Przeniósł się wówczas na wydział ekonomiczno-prawny i rozpoczął pracę w Banku Przemysłowców w Poznaniu. W roku 1924 wstąpił do Seminarium Duchownego, a w 1929 r., przyjął święcenia kapłańskie. W latach 30 został skierowany na studia z zakresu historii Kościoła, które odbył na Uniwersytecie Warszawskim. Po II wojnie światowej w 1945 r. został powołany na kustosza Archiwum i Muzeum Archidiecezjalnego w Poznaniu. Aktywnie działał również w Komisji Doradczej Komitetu Odbudowy Katedry Poznańskiej w latach 1948-1954. Zob. Ks. M. Banaszak, Nekrolog. Śp. Ks. Stefan Hain (19031979), MKP, 31 (1980) nr 4, s. 89-92.

${ }^{20}$ Ks. J. Stanisławski, Sylwetki Dyrektorów Archiwum, część poświęcona ks. Stanisławowi Hain.

${ }^{21}$ Ks. Profesor Marian Banaszak (1926-1997), ur. w Panience, święcenia kapłańskie przyjął w 1951 r. W 1958 r. został powołany na prefekta Arcybiskupiego Seminarium Duchownego i wykładowcę historii Kościoła. Za zgodą abpa wykładał w Akademii Teologii Katolickiej w Warszawie. W 
niaka, pragnącego by archiwum stało się nowoczesną placówką naukową udostępniającą badaczom swoje zasoby, rozpoczął pracę od remontu pomieszczeń. Następnie na bazie inwentarza pozostawionego przez ks. J. Nowackiego sporządził pierwszy informator o zasobach archiwum zatwierdzony przez Naczelną Dyrekcję Archiwów Państwowych. W krótkim czasie ks. M. Banaszak zorganizował również pracownię introligatorsko-konserwatorską, której zadania z czasem poszerzono o konserwację papieru. Renowacji poddawano w pierwszej kolejności akta Kancelarii Arcybiskupiej oraz najbardziej zniszczone księgi staropolskie ${ }^{22}$. Ponadto podjęto się zmikrofilmowania archiwaliów z okresu staropolskiego oraz zbioru ksiąg metrykalnych. Zmiany nastąpiły również w samej organizacji archiwum. Liczba osób obsługujących ówczesna placówkę wzrosła do 9, podobnie jak liczba osób korzystających z jej zasobu. W związku z tym w 1973 r. archiwum zyskało kolejne dwa ważne dokumenty, regulujące jego prace: Tymczasowy Statut Archiwum Archidiecezjalnego w Poznaniu oraz Tymczasowy Regulamin czytelni w Archiwum Archidiecezjalnym w Poznaniu ${ }^{23}$. Oba dokumenty uzupełniały dotychczasowy statut abpa E. Dalbora tak, aby przystosować je do zaistniałych zmian organizacyjnych i personalnych. Swoją pracę w archiwum ks. Banaszak zakończył już wolnej Polsce, w 1990 r.

Schedę po zmarłym dyrektorze przejął ks. Konrad Lutyńskii ${ }^{24}$. Pozostał on na tym stanowisku do $2002 \mathrm{r}$. Swoją prace w archiwum rozpoczą jeszcze u boku swego poprzednika, jako kustosz. Przejmując obowiązki dyrektora w 1990 r., za swoje główne zadanie uważał doprowadzenie do całkowitej komputeryzacji przejętej placówki. W 2002 r., po śmierci ks. Lutyńskiego, na jego miejsce mianowany został ks. kanonik mgr. lic. Roman Dworacki, obecny dyrektor archiwum. W trakcie jego dotychczasowej kadencji Archiwum Archidiecezjalne zostało przeniesione z Akademii Lubrańskiego (obecnie siedziba Muzeum Archidiecezjalnego) do wyremontowanego, stojącego vis a vis muzeum, budynku przy ul. Ignacego Posadzego 2. Rozpoczęto bardzo intensywny proces jego przystosowywania do współczesnych wymogów i standardów placówek naukowych. Archiwum zaczęto wyposażać w nowoczesne rozwiązania i technologie służące do zabezpieczania zgromadzonego zasobu. Począwszy od 2009 r. za pomocą aparatu cyfrowego

swoim dorobku naukowym miał ponad 600 publikacji, w tym wielotomową Historię Kościoła Katolickiego wydaną w latach 1987-1992. Zob. Ks. K. Lutyński, Nekrolog. Ksiądz Marian Banaszak (1926-1997), MKP, 49 (1998) nr 5, s. 27-40.

${ }^{22}$ Ks. J. Stanisławski, Sylwetki Dyrektorów Archiwum, część poświęcona ks. Marianowi Banaszakowi.

${ }^{23}$ F. Lenort, 50 lat Archiwum Archidiecezjalnego w Poznaniu, „Poznańskie Studia Teologiczne", 3 (1981) s. 328.

${ }^{24}$ Ks. kanonik dr Konrad Lutyński (1940-2002), ur. w Krobi, święcenia kapłańskie przyjął w 1964 r. W latach 1971-1974 studiował na Katolickim Uniwersytecie Lubelskim. Wykładał historię Kościoła na Papieskim Wydziale Teologicznym w Poznaniu. Z czasem mianowany został adiunktem na Wydziale Teologicznym UAM w Zakładzie Historii Kościoła. W latach 1989-1999 był członkiem Komisji Episkopatu do spraw Sztuki i Archiwów. Był również stałym członkiem Głównego Zarządu Stowarzyszenia Archiwistów Polskich oraz Komisji Teologicznej Poznańskiego Towarzystwa Przyjaciół Nauk. Zob. Ks. J. Grzemski, Nekrolog. Ksiądz Konrad Lutyński (19402002). Kazanie wygloszone na pogrzebie, MKP, 54 (2003) nr 8, s. 32-36. 
wykonywano kopie najstarszych i najcenniejszych jednostek, zaś od 2013 r. do digitalizacji zasobu używany jest specjalny skaner dla materiałów archiwalnych. Powstałe $\mathrm{w}$ ten sposób dokumenty elektroniczne zapisywane są w programie komputerowym wykonanym na zamówienie archiwum. Ponadto wprowadzono również nowe metody opisu pojedynczych jednostek, a co za tym idzie porządkowania zespołów archiwalnych. Opracowane zespoły i jednostki zarejestrowane w komputerowej bazie danych prócz tradycyjnych sygnatur są oznaczane za pomocą osobnych kodów kreskowych. Rozwiązania te stosowane od dłuższego czasu w bibliotekach, ma na celu uproszczenie drogi udostępniania dokumentów oraz umożliwienie stałej kontroli nad zasobem tak, aby uniknąć ewentualnych braków.

W 2004 r. archiwum zyskało nowy statut. Został on ogłoszony 25 września 2004 r. na Synodzie biskupim, który obradował w latach 2004-2008 pod przewodnictwem metropolity poznańskiego abpa Stanisława Gądeckiego. Dokument ten określa podstawę prawną funkcjonowania archiwum, jego władze administracyjne, definiuje, jakie zabytki archiwalne stanowią zasób archiwum oraz wskazuje możliwości jego poszerzania ${ }^{25}$.

Obecnie w zbiorach Archiwum Archidiecezjalnego znajduje się 3.600 metrów bieżących akt, w tym najcenniejsze i budzące największą ciekawość księgi metrykalne. Archiwalia pogrupowane są w 169 zespołach, do których zaliczyć należy 1.085 dokumentów pergaminowych 14.114 dokumentów papierowych, 1.078 listów, 2.504 ksiąg rękopiśmiennych urzędów centralnych diecezji, około 50.721 akt nowożytnych, 2.097 rękopisów (XVII-XX), 799 inkunabułów oraz 3.508 starodruków (XVI-XVII w.). Wymieniony zasób stanowią archiwalia pochodzące z kancelarii biskupiej, kapitulnej i konsystorskiej, akta wytworzone przez biskupów i arcybiskupów poznańskich, konsystorz i kurię arcybiskupią, Metropolitalny Sąd Duchowny oraz Kapitułę Metropolitalną. W Archiwum zgromadzono także liczne źródła do dziejów poznańskich zakonów oraz ważnych instytucji kościelnych $\mathrm{z}$ terenu archidiecezji, jak akta Arcybiskupiego Seminarium Duchownego, Caritasu czy Akcji Katolickiej ${ }^{26}$.

Archiwum stale, $\mathrm{z}$ ogromna troską i dbałością pracuje nad tym, aby zapewnić archiwaliom odpowiednie przechowanie i zabezpieczenie przed zniszczeniem. Jest to zgodne $\mathrm{z}$ celem, jaki przyświecał archiwum od początku działalności, by zachować pamięć o dziejach Kościoła Katolickiego w Polsce, a tym samym o historii naszego kraju. W 2015 r. przypadła 90. rocznica działalności tej zacnej placówki. W tym celu w dniach 3-4 listopada 2015 r. Archiwum Archidiecezjalne, na pamiątkę okrągłej rocznicy zorganizowało obchody, które swym patronatem objął J.E. Arcybiskup dr Stanisław Gądecki metropolita poznański.

Uroczystości w dniu 3 listopada otworzyło spotkanie zatytułowane Dyrektorskie rozmowy o archiwum. Odbywało się ono pod przewodnictwem samego metropolity. Udział w nim wzięli dyrektorzy archiwów kościelnych z całej Polski, zaś gościem honorowym wtorkowej sesji miał być bp Sergio Pagano - Prefekt

${ }^{25}$ Statut Archiwum Archidiecezjalnego w Poznaniu, w: Synod Archidiecezji Poznańskiej (20042008), zwołany i przeprowadzony przez Arcybiskupa Stanisława Gądeckiego, T. II: Statuty, Poznań 2008, s. 172-173.

${ }^{26}$ Wstęp, w: „Archiwariusz”, 1 (2005) s. 1-2. 
Tajnego Archiwum Watykańskiego. Niestety śmierć jednego z członków rodziny uniemożliwiła mu uczestnictwo w uroczystościach.

Głównym tematem spotkania z Metropolitą było podsumowanie dotychczasowej działalności archiwów kościelnych w Polsce. Omówiono problematykę podstawowych zadań i celu tych instytucji. W kolejnej części zaprezentowano sposób wykorzystania najnowszych narzędzi informatycznych w zakresie opisu i wyszukiwania dokumentów, ich konserwacji czy przechowywania w nowych formatach. Spotkanie w gronie dyrektorów było również okazją do wymiany dotychczasowych doświadczeń na polu pracy archiwalnej. Obrady zakończyły się wspólną kolacją.

Drugi dzień obrad 4 listopada otworzyła msza św. odprawiona w kaplicy Arcybiskupiego Seminarium Duchownego w Poznaniu przy ul. Wieżowej 2/4. Po jej zakończeniu zaproszeni goście przenieśli się do siedziby Archiwum Archidiecezjalnego gdzie odbyła się uroczysta sesja naukowo-wspomnieniowa. Uczestniczyło w niej ponad 60 zaproszonych gości. Swoją obecnością w tym dniu zaszczycili archiwum m.in.: księża prałaci Marian Lewandowski oraz Jan Stanisławski, dyrektorzy archiwów archidiecezjalnych i diecezjalnych w Polsce m.in.: ks. dr Michał Sołomieniuk (Gniezno), ks. dr Robert Masalski (Szczecin), ks. dr Andrzej Kwaśniewski (Kielce), ks. dr. hab. Robert Kufel (Zielona Góra), ks. dr Sławomir Kęszka (Kalisz) oraz ks. dr hab. Waldemar W. Żurek, prof. KUL (Ośrodek Archiwów Bibliotek i Muzeów Kościelnych KUL). Podobnie jak 90 lat temu, na uroczystościach pojawił się przedstawiciel Naczelnej Dyrekcji Archiwów Państwowych w Polsce dr hab. Władysław Stępniak, Dyrektor NDAP. Swoją obecnością zaszczyciła archiwum również mgr Jolanta Goszczyńska Wielkopolski Wojewódzki Konserwator Zabytków oraz wielu innych znamienitych gości.

Po przywitaniu zebranego audytorium przez dyrektora ks. Romana Dworackiego, w imieniu metropolity poznańskiego abpa Stanisława Gądeckiego głos zabrał ks. prałat Jan Stanisławski, przedstawiciel Rady Formacji Kapłanów Archidiecezji Poznańskiej. Odczytał on list ordynariusza skierowany do uczestników uroczystej sesji. Arcybiskup w słowach uznania podkreślił, że archiwum swoją działalnością oraz organizacją jubileuszu wyprzedza i jednocześnie wpisuje się w obchody 1050. rocznicy Chrztu Polski. Podkreślił jednocześnie, że

Archiwum Archidiecezjalne nie jest martwym zbiorem dokumentów, ale w każdym calu świadectwem wiary i kultury oraz 1050-letniego chrześcijaństwa na ziemiach polskich ${ }^{27}$.

Kończąc przekazał na ręce uczestników życzenia oraz zapewnił o modlitwie.

Listę prelegentów miał otwierać bp Sergio Pagano z odczytem La ricera nell Archivio Segreto Apostolico Vaticano: possibilita `e limiti (Kwerenda w Tajnym Archiwum Watykańskim: możliwości i ograniczenia). Niestety ze względu, na wspomniane wcześniej przyczyny referat ten został zastąpiony obszernym résumé ks. prał. J. Stanisławskiego, zatytułowanym Sylwetki Dyrektorów Archiwum Ar-

${ }^{27}$ Cyt. Za: S. Gądecki, Stowo wstepne na otwarcie 90-lecia Archiwum Archidiecezjalnego w Poznaniu, wygłoszone w imieniu ks. Arcybiskupa Stanisława Gądeckiego przez ks. Prałata Jana Stanisławskiego w dniu 04.11.2015. 
chidiecezjalnego w Poznaniu - wspomnienie, prezentującym historie Archiwum Archidiecezjalnego w oparciu o życiorysy i opis sylwetek jego dyrektorów.

W nawiązaniu do rozmów w dniu poprzednim, dotyczących działalności archiwów kościelnych z podsumowaniem zatytułowanym Między rocznicami, czyli pięć lat z działalności Archiwum Archidiecezjalnego w Poznaniu 2010-2015 wystąpił wicedyrektor archiwum ks. dr Jan Maria Musielak. Wychodząc od przypomnienia zadań archiwum zawartych w nowym statucie z 2004 r. przedstawił w prezentacji multimedialnej pięcioletnią działalność poznańskiej placówki w tym zgromadzony zasób, innowacyjne metody jego przechowywania i zabezpieczenia. Do istotniejszych zadań archiwum należałoby zaliczyć intensywną i otwartą działalność edukacyjną oraz szeroką współpracę na tym polu z innymi placówkami naukowymi. Zacieśnianiu takich relacji służą w szczególności lekcje żywej historii zatytułowane Warsztaty archiwalno-historyczne prowadzone dla szkół gimnazjalnych, ponadgimnazjalnych, studentów Uniwersytetu im. Adama Mickiewicza w Poznaniu oraz Uniwersytetów Trzeciego Wieku. Od 2011 r. archiwum jest współorganizatorem Turnieju Piłki Nożnej Arch-Footboll, który poprzez rekreację i formę pikniku zrzesza środowiska naukowe całego Poznania. Uczestnikami przez ostatnie lata były: Archiwum Państwowe w Poznaniu wraz z oddziałami w Lesznie i Wrocławiu, Instytut Pamięci Narodowej oddział w Poznaniu, Biblioteka Uniwersytecka UAM, Biblioteka Raczyńskich oraz Wydział Historii UAM. Taka forma wspólnie spędzanego czasu pozwoliła na zawiązanie bardzo życzliwych a wręcz przyjacielskich relacji.

Momentem szczególnym w czasie sesji było wręczenie dyplomów Amicus Archivi Archidioecesialis Posnaniensis. Zostały one specjalnie przygotowane i skierowane do przedstawicieli instytucji stale współpracujących z archiwum, jak również do hojnych darczyńców, bez których pomocy finansowej i merytorycznej praca archiwum byłaby znacznie trudniejsza. Wśród wyróżnionych znaleźli się Dyrektor Archiwum Państwowego w Poznaniu mgr Henryk Krystek, ks. prałat Stanisław Lewandowski, ks. prałat Artur Przybył, ks. Tadeusz Magas, dyrektor Domu Medialnego św. Wojciech (dawniej Księgarnia i Drukarnia św. Wojciecha) ks. dr Tomasz Siuda. Miłym zaskoczeniem okazał się prezent, jaki Archiwum Państwowe przygotowało na 90-lecie archiwum. Była to kopia jednostki archiwalnej zawierająca korespondencję władz Kościoła poznańskiego z 1926 r. z wydziałem archiwów państwowych przy Ministerstwie Wyznań Religijnych i Oświecenia Publicznego, informującej o powstaniu archiwum, program inauguracji otwarcia oraz adres gratulacyjny od Naczelnika Wydziału Archiwów przy M.R. i O.P. pana Józefa Paczkowskiego ${ }^{28}$.

Po wręczeniu dyplomów, nadszedł czas na okolicznościowe wystąpienia i odczytanie adresów gratulacyjnych. Wyrazy uznania dla dotychczasowego dorobku Archiwum oraz życzenia dalszego rozwoju przesłali:

W imieniu Naczelnej Dyrekcji Archiwów Państwowych, Naczelny Dyrektor dr hab. Władysław Stępniak, który w tych słowach wyraził swoje uznanie dla działalności archiwum:

(...) instytucja realizująca $\mathrm{w}$ sposób bardzo profesjonalny porównywalny

${ }^{28}$ APP, 999/30. 
a w niektórych przypadkach przewyższający poziom pracy archiwów państwowych. Spełnia wszystkie wymogi, zabezpieczenia, opracowania i udostępniania pięknych map. Posiada fantastyczne zbiory, reprezentuje wysoki poziom prac merytorycznych, profesjonalność i nowoczesność.

W imieniu Archiwum Państwowego w Poznaniu, mgr Henryk Krystek. Na uwagę zasługują słowa dyrektora zawarte w liście:

$\mathrm{Z}$ podziwem odnotowujemy, jak wiodąca jednostka, nie tylko wśród polskich archiwów kościelnych, dzięki bardzo dobrej organizacji oraz operatywności Dyrekcji, a nade wszystko przychylności i zrozumieniu władz Archidiecezji Poznańskiej, nadaje ton i wytycza nowe standardy w zakresie zabezpieczenia, opracowania, digitalizacji i udostępniania materiałów archiwalnych ${ }^{29}$.

W imieniu Polskiej Akademii Nauk, gratulacje przesłał Kierownik Poznańskiego Oddziału Archiwum Polskiej Akademii Nauk dr Jarosław Matysiak; w imieniu Instytutu Pamięci Narodowej Oddział w Poznaniu, dyrektor Oddziału dr Rafał Reczek; w imieniu Biblioteki Kórnickiej PAN, dyrektor prof. Tomasz Jasiński; w imieniu członków Poznańskiego Towarzystwa Przyjaciół Nauk, dr hab. Andrzej Gulczyński, prof. UAM; Wielkopolski Wojewódzki Konserwator Zabytków, Jolanta Goszczyńska; w imieniu Archiwum Państwowego w Lesznie, dyrektor mgr Elżbieta Olender; w imieniu Wydziału Historycznego Uniwersytetu im. Adama Mickiewicza w Poznaniu, dziekan prof. dr hab. Kazimierz Ilski. W imieniu Instytutu Historii Uniwersytetu im. Adama Mickiewicza w Poznaniu, z-ca dyrektora dr hab. Przemysław Matusik, prof UAM; kierownik Zakładu Archiwistyki Uniwersytetu im. Adama Mickiewicza w Poznaniu, dr hab. Irena Maczak-Gadkowska, prof. UAM; w imieniu Diecezjalnego Instytutu Akcji Katolickiej Archidiecezji Poznańskiej, prezes zarządu Bogumiła Kania-Łącka; w imieniu Domu Medialnego Święty Wojciech sp. z.o.o., prezes zarządu ks. dr Tomasz Siuda.

Ostatnim akcentem spotkania była prezentacja filmu promocyjnego Praca za pokolenia dla pokoleń, przygotowanego przez archiwum dla przybliżenia uczestnikom jubileuszu swojej historii, celów, jako instytucji, dotychczasowych osiągnięć oraz sylwetki pracowników stanowiących bardzo istotne wsparcie merytoryczne i administracyjne instytucji. Cała uroczystość została uwieńczona koncertem muzyki kameralnej w wykonaniu zespołu muzyki dawnej Brille Ensemble, stworzonego przez studentów Zakładu Instrumentów Historycznych Akademii Muzycznej im. Ignacego Jana Paderewskiego w Poznaniu.

Jubileusz 90-lecia Archiwum Archidiecezjalnego w Poznaniu był szeroko relacjonowany $w$ mediach regionalnych, takich jak Radio Emaus, w programie telewizyjnym $Z \dot{z}$ ycia Kościoła wyemitowanym w dniu 08.11.2015 przez Oddział TVP3 Poznań, w dodatku „Metropolii Poznańskiej” do „Przewodnika Katolickiego" 30 oraz na portalu eKai.pl ${ }^{31}$.

\footnotetext{
${ }^{29}$ List gratulacyjny Dyrektora Henryka Krystka dla Dyrektora Archiwum Archidiecezjalnego w Poznaniu Ks. Romana Dworackiego, datowany na 4 listopada 2015.

${ }^{30}$ B. Tobolski, 90 lat Archiwum, „Przewodnik Katolicki”, 121 (2015) nr 45, Dodatek PK „Metropolia Poznańska", s. 2-3.

${ }_{31}$ Tenże, Poznań: 90 lat Archiwum Archidiecezjalnego, http://ekai.pl/diecezje/poznanska/ x93866/poznan-lat-archiwum-archidiecezjalnego (dostęp: 04.11.2015).
} 


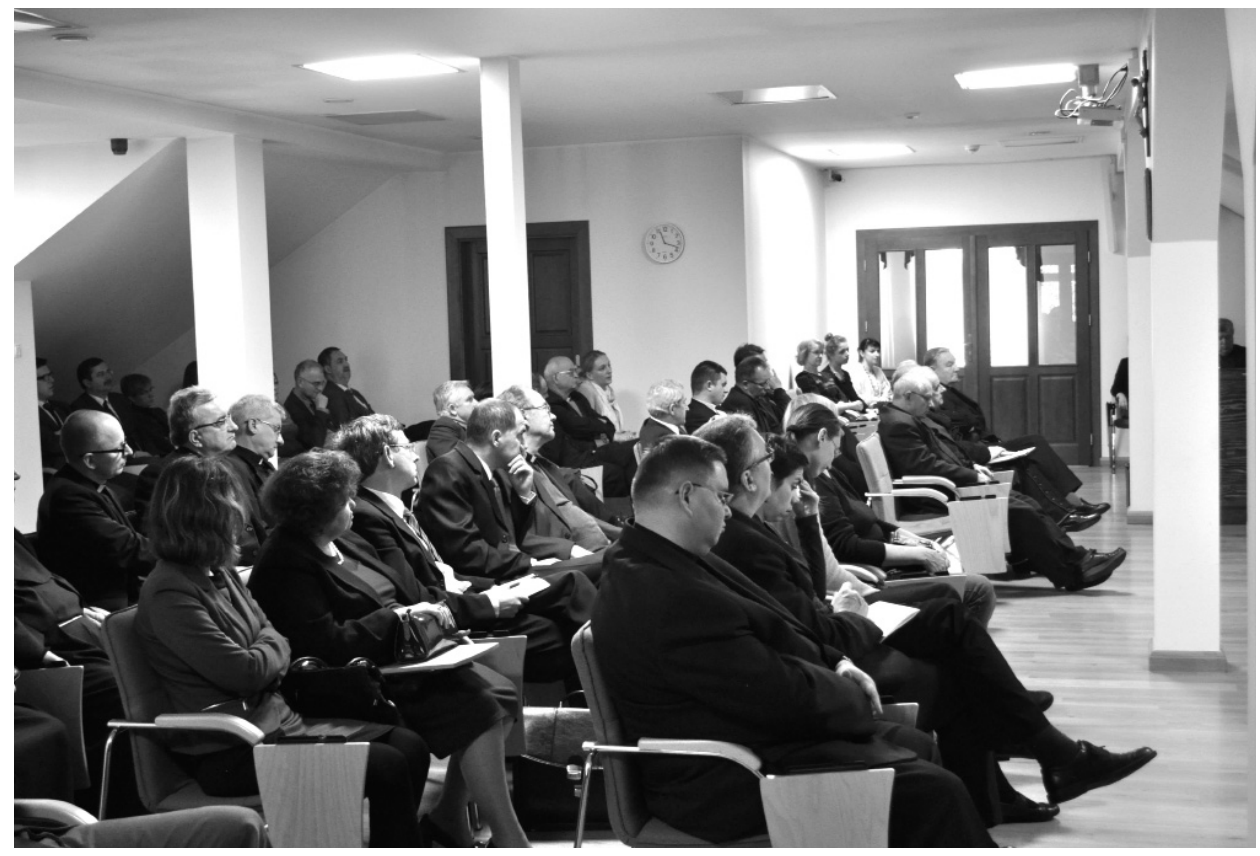

Fot. 2. Uczestnicy sesji 90. lecia Archiwum Archidiecezjalnego Poznaniu, ze zbiorów AAP.

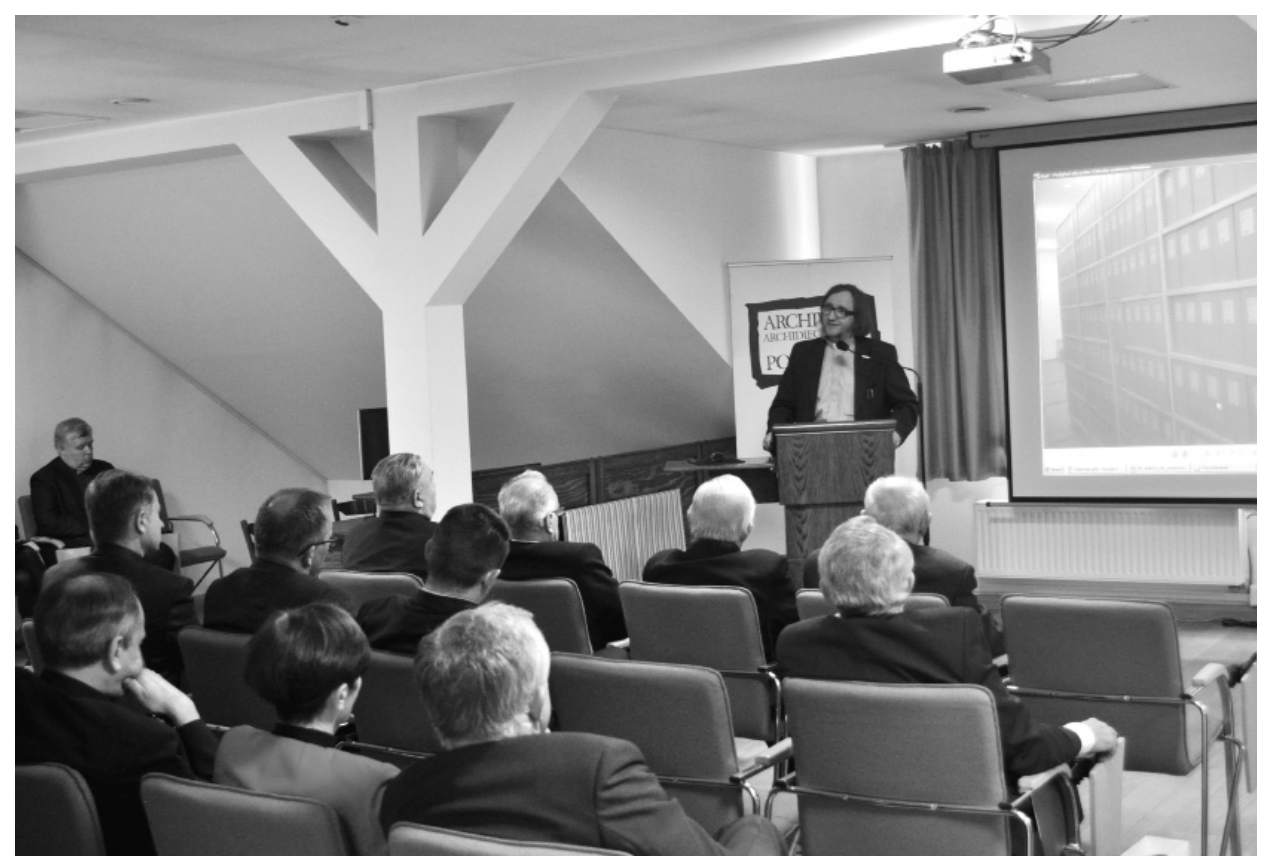

Fot. 3. Ks. dr Jan Maria Musielak, wicedyrektor Archiwum Archidiecezjalnego w Poznaniu, ze zbiorów AAP. 


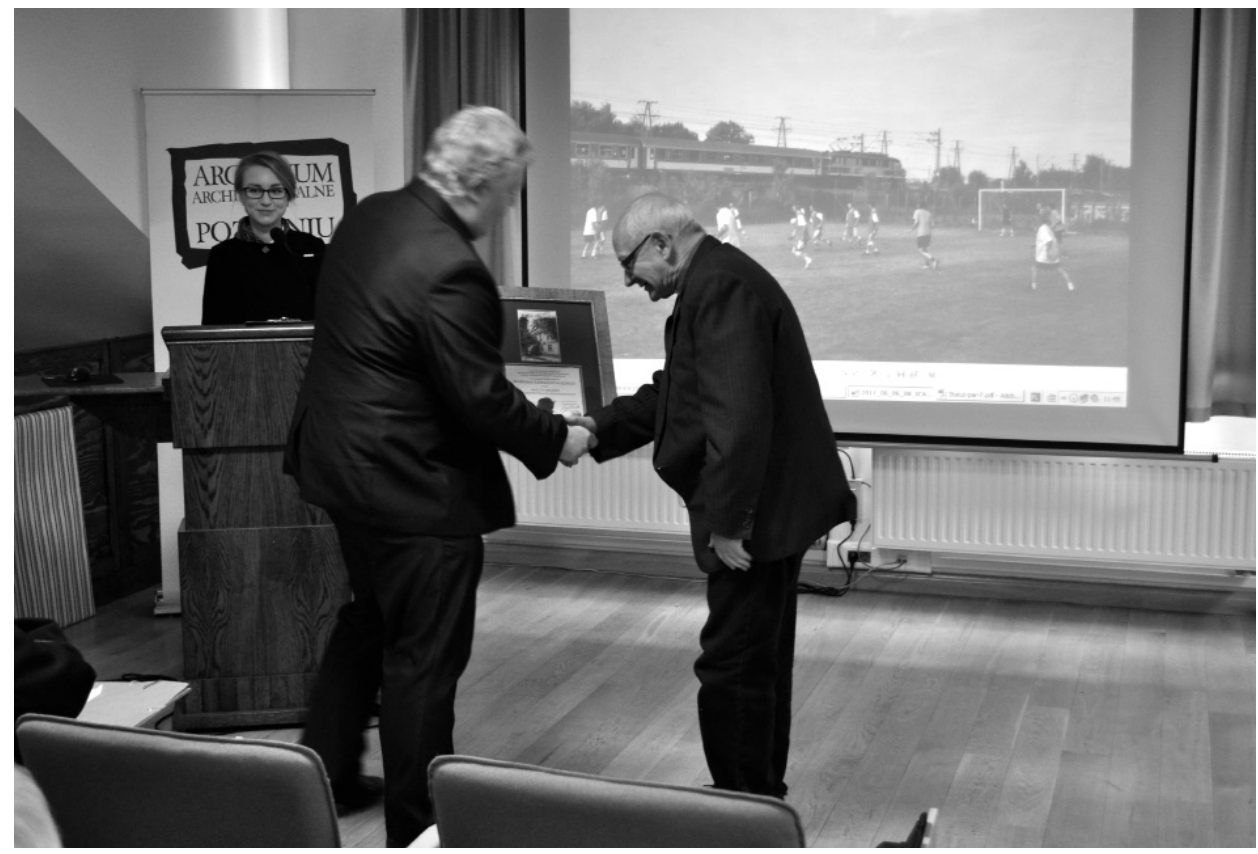

Fot. 4. Wręczenie dyplomu Amicus Archivi Archidioecesialis Posnaniensis (od prawej: ks. Roman Dworacki, dyrektor Archiwum Archidiecezjalnego w Poznaniu oraz ks. prałat Marian Lewandowski), ze zbiorów AAP.

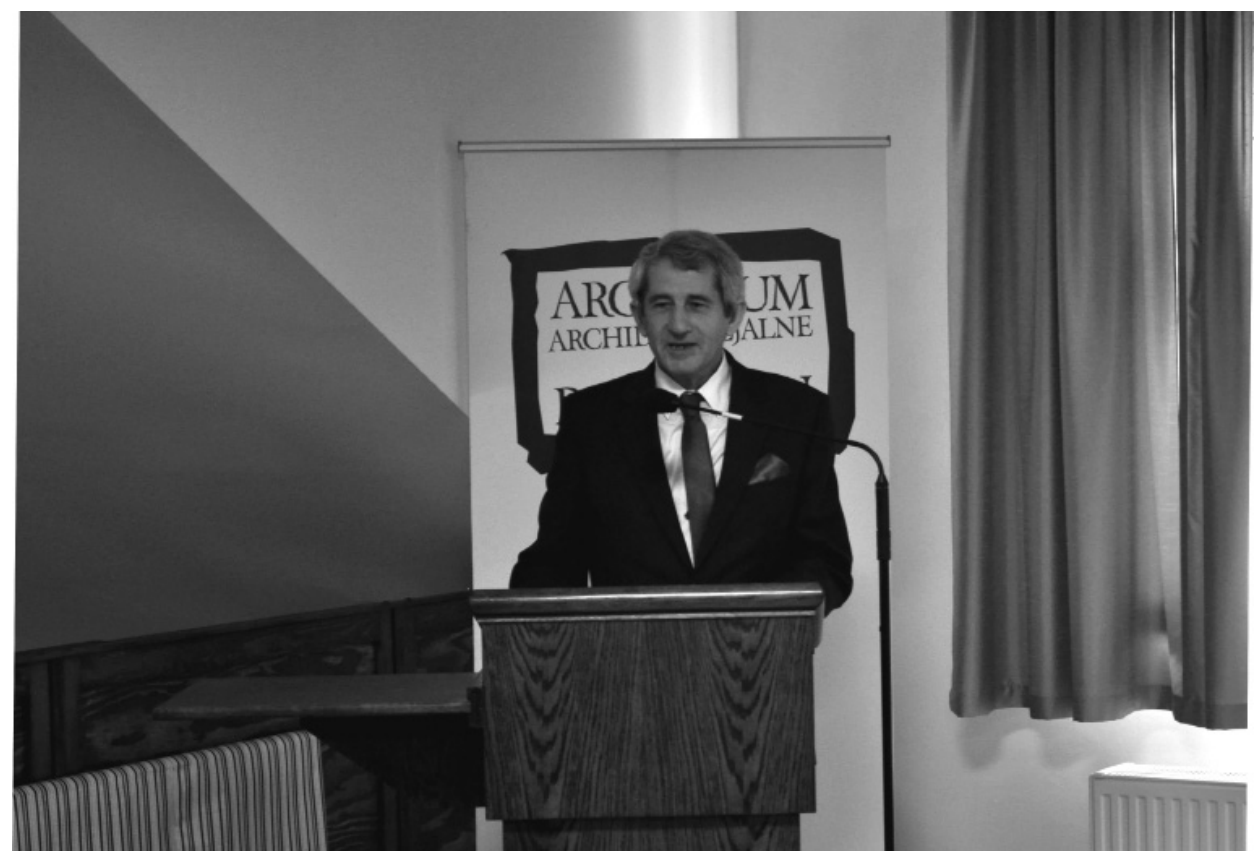

Fot. 5. Odczytanie listu gratulacyjnego przez Naczelnego Dyrektora Archiwów Państwowych dr hab. Władysława Stępniaka, ze zbiorów AAP. 